\title{
INFEKSI VIRUS DENGUE PADA ANAK DI BLU PROF. DR. R. D KANDOU MANADO PERIODE JULI 2011 SAMPAI JUNI 2012
}

\author{
${ }^{1}$ Nurul Handayani \\ ${ }^{2}$ Standy Soeliongan, \\ ${ }^{2}$ Fredine Rares
}

\author{
${ }^{1}$ Kandidat Skripsi Fakultas Kedokteran Universitas Sam Ratulangi Manado \\ ${ }^{2}$ Bagian Mikrobiologi Fakultas Kedokteran Universitas Sam Ratulangi Manado \\ Email: nurulhandayani32@yahoo.co.id
}

\begin{abstract}
More than a third of the world's population live in areas at risk of infection. Dengue virus is a major cause of illness and death in the tropics and subtropics. As many as 400 million people are infected each year. Dengue is caused by one of four related viruses transmitted by mosquitoes. This study used a descriptive method by summarizing and reviewing the materials existing literature . Samples in this study were all patients suffering from dengue fever were entered in the Children's Section BLU Prof Dr . DR.RD Kandou Manado period July 2011 - June 2012 . Once all the data has been summarized , the data is collected and entered into the computer. The results showed that there was no difference in the number of children infected with dengue fever, which is same between women and men. Most girls are infected with dengue virus are at school age (5-12 years) as many as 14 people. At least is the age of the baby and play by 5 people. Most boys are infected with dengue virus are at school age , 5-12 years of age minister to as many as 15 people. At least is the age to play as many as 2 people. The entire girls and boys experience an increase in erythrocytes, platelets and leukocytes decrease. Conclusion: The number of girls and boys who are the same infected dengue fever which is 50:50. The most natural in children between 5-12 years of age both in girls and boys. At least in the natural at 1-2.5 year olds both in girls and boys. The entire girls and boys experience an increase in erythrocytes , platelets and leukocytes decrease .
\end{abstract}

Keywords: dengue infection, dengue fever .

Abstrak: Lebih dari sepertiga dari populasi dunia tinggal di daerah yang berisiko terinfeksi, virus dengue merupakan penyebab utama penyakit dan kematian di daerah tropis dan subtropis. Sebanyak 400 juta orang terinfeksi setiap tahun. Dengue disebabkan oleh salah satu dari empat virus terkait ditularkan oleh nyamuk. Penelitian ini menggunakan metode deskriptif, yakni dengan cara merangkum dan mengkaji bahan-bahan kepustakaan yang ada. Sampel pada penelitian ini adalah seluruh pasien yang menderita demam dengue yang masuk di Bagian Anak BLU RSUP Prof. DR.R.D Kandou Manado periode Juli 2011 - Juni 2012.Setelah semua data telah rangkum, data dikumpulkan dan dimasukkan kedalam komputer. hasil penelitian memperlihatkan tidak terdapat perbedaan jumlah anak yang terinfeksi demam dengue, yakni sama jumlahnya antara perempuan dan laki-laki. Paling banyak anak perempuan yang terinfeksi virus dengue adalah pada usia sekolah, yakni usia 512 tahun sebanyak 14 orang. Paling sedikit adalah pada usia bayi dan bermain yanitu sebanyak 5 orang. Paling banyak anak laki-laki yang terinfeksi virus dengue adalah pada usia sekolah, yani usia 5-12 tahun sebanyak 15 orang. Paling sedikit adalah pada usia bermain 
yaitu sebanyak 2 orang. Seluruh anak perempuan dan anak laki-laki mengalami peningkatan eritrosit, penurunan trombosit dan leukosit.Simpulan: Jumlah anak perempuan dan anak lakilaki yang tefinfeksi demam dengue adalah sama yakni 50:50. Paling banyak di alami pada usia anak antara 5-12 tahun baik pada anak perempuan maupun laki-laki. Paling sedikit di alami pada usia anak antara 1-2,5 tahun baik pada anak perempuan maupun laki-laki. Seluruh anak perempuan dan anak laki-laki mengalami peningkatan eritrosit, penurunan trombosit dan leukosit.

Kata kunci : Infeksi dengue, demam dengue.

Lebih dari sepertiga dari populasi dunia tinggal di daerah yang berisiko terinfeksi, virus dengue merupakan penyebab utama penyakit dan kematian di daerah tropis dan subtropis. Sebanyak 400 juta orang terinfeksi setiap tahun. Dengue disebabkan oleh salah satu dari empat virus terkait ditularkan oleh nyamuk. Belum ada vaksin untuk mencegah infeksivirus dengue dan tindakan perlindungan yang paling efektif adalah menghindari gigitan nyamuk. Ketika terinfeksi, pengenalan dini dan pengobatan suportif yang cepat secara substansial dapat menurunkan risiko komplikasi medis dan kematian. Dengue telah muncul sebagai masalah di seluruh dunia hanya sejak tahun 1950-an. Meskipun dengue jarang terjadi di daratan Amerika Serikat, namun merupakan wilayah endemik di Puerto Rico dan banyak tujuan wisata populer di Amerika Latin, Asia Tenggara dan pulau-pulau Pasifik. $^{1-3}$

Infeksi virus dengue merupakan penyakit virus yang ditularkan oleh nyamuk yang paling cepat penyebarannya di dunia. Penyakit demam berdarah dengue di Indonesia terjadi pertama kali di Surabaya pada tahun 1968 dengan penderita 58 orang dan 24 orang meninggal dunia. Di Indonesia tahun 2007 terdapat 157.839 kasus dilaporkan dengan 1.597 orang pasien meninggal yang merupakan laporan kasus tertinggi dibandingkan tahun sebelumnya. Data Departemen Kesehatan menyebutkan bahwa jumlah keseluruhan kasus demam berdarah dengue secara nasional pada tahun 2008 mencapai 133.402 penderita, $1.141 \mathrm{di}$ antaranya meninggal dunia. ${ }^{2,4}$
Demam berdarah dengue (DBD) merupakan salah satu masalah kesehatan di daerah tropis. DBD merupakan salah satu penyakit infeksi yang disebabkan oleh virus dengue. Gejala klinis infeksi virus dengue beragam mulai tanpa gejala, demam ringan, demam dengue, demam berdarah dengue hingga sindroma renjatan (syok). Trombositopenia merupakan salah satu patokan (kriteria) laboratorik untuk menetapkan diagnosis DBD yang telah dikukuhkan oleh WHO pada tahun 1997. 1,5

Pencegahan dapat dilakukan dengan mengontrol vektornya yaituAedes aegepty. Manajemen lingkungan, kontrol biologi dan kontrol kimia merupakancara yang efektif dalam memberantas perkembangbiakan dari Aedes aegepty. Keberhasilan pencegahannya membutuhkan partisipasi masyarakat. Pengetahuan tentang penyakit serta pencegahannya menjadi hal yang penting diketahui olehmasyarakat. Di tingkat keluarga pun begitu. Hendaknya orang tua khususnya ibu,yang memang memiliki peran untuk mengelola rumah tangga di rumah, memiliki pengetahuan yang cukup tentang penyakit serta pencegahannya. Rendahnya pengetahuan tentunya sejalan dengan munculnya risiko terkena penyakit. Dengandemikian, jika keluarga khususnya ibu memiliki pengetahuan yang cukup mengenaipenyakit DBD serta pencegahannya, maka anak-anak pun dapat terhindar dari risikoterkena DBD maupun DD. ${ }^{6-8}$

Nyamuk Aedes aegypti berasal dari Afrika Timur, kemudian menyebar kearah timur dan barat, di daerah tropis dan 
subtropis pada batas lintang $40^{\circ}$ lintang utara dan $40^{\circ}$ lintang selatan. Nyamuk ini tersebar luas di daerah tropis dan subtropis di asia tenggara, terutama di daerah perkotaan. Penyebaran nyamuk kelingkungan pedesaan disebabkan adanya perbaikan sarana transportasi dan pengembangan sarana suplai air sampai kepedesaan. Ketinggian dari pemukaan laut merupakan faktor yang paling penting bagi penyebaran nyamuk Aedes aegypti. ${ }^{9}$ Menurut penelitian yang paling berperan pada penularan penyakit adalah Aedes aegypti. Hal ini disebabkan oleh beberapa alasan, antara lain karena habitat nyamuk ini berada didalam dan sekitar

\section{METODE PENELITIAN}

Jenis penelitian yang digunakan yaitu penelitian yang bersifat deskriptif yakni dengan merangkum dan mengkaji bahan-bahan kepustakaan yang ada. Penelitian ini dilakukan di RSUP Prof. DR.R.D Kandou Manado pada periode Juli 2011 hingga Juni 2012. Sumber data diperoleh secara sekunder yaitu

\section{HASIL PENELITIAN}

Penelitian yang dilakukan di Bagian Anak RSU Prof. Dr. R. D. Kandou Manado periode Juli 2011 sampai Juni 2012, merupakan penelitian yang bersifat deskriptif. Dalam rentang waktu tersebut, peneliti berhasil mengumpulkan data sejumlah 60 anak. Yakni 30 orang anak perempuan dan 30 orang anak laki-laki

Tabel 1. Perbandingan Jumlah Anak

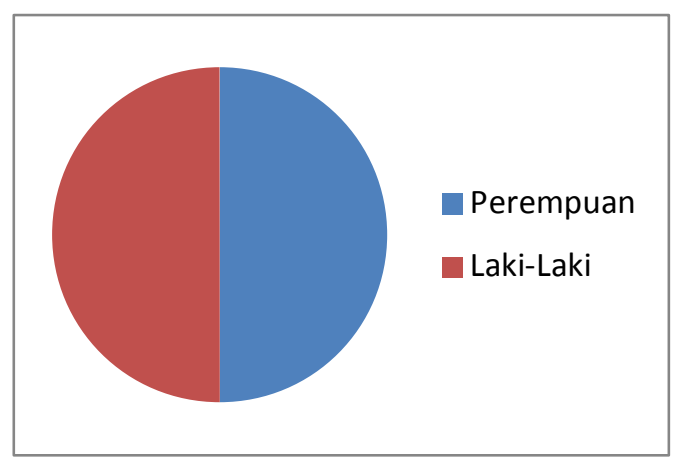

rumah. Semantara menurut Gubler (1995), virus dengue itu sendiri merupakan bagian dari flaviviridae dan dapat diklasifikasikan dalam empat serotipe yaitu serotipe Dengue-1, Dengue-2, Dengue-3 dan Dengue-4. Dari keempat serotipe tersebut yang paling sering menyebabkan kasus $\neg$ kasus berat dan menyebabkan kematian adalah serotipe Dengue-3. ${ }^{10}$

Publikasi mengenai infeksi dengue pada anak sangat terbatas, oleh karena itu peneliti ingin membahas lebih lanjut mengenai Infeksi Virus Dengue pada Anak di BLU RSUP Prof. DR.R.D Kandou Manado.

pengambilan secara tidak langsung. Sampel yang digunakan yaitu sebanyak 60 orang ibu yang di ambil berdasarkan pasien yang terinfeksi demam dengue yang masuk di Bagian AnakBLU RSUP Prof. DR.R.D Kandou Manado. Setelah semua data telah rangkum, data kemudian dikumpulkan untuk dimasukkan ke dalam komputer.

Dari data yang didapatkan tampak bahwa perbedaan jenis kelamin antara anak perempuan dan anak laki-laki tidak berpengaruh. Perbandingan keduanya yakni 50:50 dimana jumlah anak yang terinfeksi demam dengue sama jumlahnya antara anak perempuan dan anak laki-laki. 
Tabel 2.Distribusi berdasarkan Usia (Perempuan)

$\begin{array}{cc}\text { Usia Anak } & \text { Perempuan } \\ \text { Bayi (0-1 tahun) } & 5 \\ \text { Bermain (1-2,5 tahun) } & 5 \\ \text { Pra sekolah (2,5-5 tahun) } & 6 \\ \text { Sekolah (5-12) } & 14 \\ \text { Total } & 30\end{array}$

Dari data yang didapatkan bahwa paling banyak anak perempuan yang terinfeksi virus dengue adalah pada usia sekolah, yakni usia 5-12 tahun sebanyak 14 orang. Di susul pada usia bermain (1-2,5 tahun) sebanyak 6 orang.

Tabel 3.Distribusi berdasarkan Usia (Laki-laki)

$$
\text { Usia Anak }
$$

Bayi (0-1 tahun)

Bermain (1-2,5 tahun)

Pra sekolah (2,5-5 tahun)

Sekolah (5-12)

Total
Laki-laki

9

2

4

15

30

Dari data yang didapatkan bahwa paling banyak anak laki-laki yang terinfeksi virus dengue adalah pada usia sekolah, yani usia 5-12 tahun sebanyak 15 orang. Di susul pada usia bermain (1-2,5 tahun) sebanyak 6 orang.

Tabel 4. Distribusi berdasarkan pemeriksaan darah lengkap

Pemeriksaan darah lengkap

\begin{tabular}{|c|c|c|c|c|c|c|}
\hline \multirow{2}{*}{$\begin{array}{c}\text { Jenis } \\
\text { Kelamin }\end{array}$} & \multicolumn{2}{|c|}{ Eritrosit } & \multicolumn{2}{|c|}{ Trombosit } & \multicolumn{2}{|c|}{ Leukosit } \\
\hline & Meningkat & Menurun & Meningkat & Menurun & Meningkat & Menurun \\
\hline Perempuan & 30 & - & - & 30 & - & 30 \\
\hline Laki-laki & 30 & - & - & 30 & - & 30 \\
\hline Jumlah & \multicolumn{2}{|c|}{60} & \multicolumn{2}{|c|}{60} & \multicolumn{2}{|c|}{60} \\
\hline
\end{tabular}

Dari tabel di atas, dapat dilihat bahwa seluruh pasien telah melakukan pemeriksaan darah lengkap. Dari pemeriksaan tersebut didapatkan hasil anak perempuan dan anak laki-laki mengalami peningkatan eritrosit, penurunan trombosit dan leukosit. 
Tabel 5. Distribusi berdasarkan pemeriksaan NS1

\begin{tabular}{|c|c|c|c|}
\hline \multirow{2}{*}{ Jenis } & \multicolumn{2}{|c|}{ Pemeriksaan NS1 } & \multirow{2}{*}{ Jumlah } \\
\cline { 2 - 4 } Kelamin & $(+)$ & $(-)$ & \\
\hline Perempuan & 15 & - & 15 \\
Laki-laki & 12 & - & 12 \\
\hline
\end{tabular}

Dari tabel diatas didapatkan bahwa dari keseluruhan pasien tidak semuanya melakukan pemeriksaan, hanya 27 orang saja yang melakukan pemeriksaan tersebut. Dari pemeriksaan tersebut didapatkan 15 orang pasien perempuan positif dan 12 orang pasien laki-laki yang positif.

Tabel 6.Distribusi berdasarkan pemeriksaan Imunoglobulin $\mathrm{M}$

\begin{tabular}{|c|c|c|c|}
\hline \multirow{2}{*}{ Jenis } & \multicolumn{2}{|c|}{$\begin{array}{c}\text { Pemeriksaan } \\
\text { Imunoglobulin }\end{array}$} & \multirow{2}{*}{ Jumlah } \\
\cline { 2 - 3 } Kelamin & \multicolumn{2}{|c|}{ IgM } & \\
\cline { 2 - 3 } Anak & $(+)$ & $(-)$ & 8 \\
\hline Perempuan & 5 & 3 & 10 \\
Laki-laki & 3 & 7 & \\
\hline
\end{tabular}

Dari tabel 6 didapatkan bahwa dari keseluruhan pasien tidak semuanya melakukan pemeriksaan IgM, hanya 18 orang saja yang melakukan pemeriksaan tersebut. Dari pemeriksaan tersebut didapatkan 8 orang pasien perempuan dan 10 orang pasien laki-laki.

Tabel 7.Distribusi berdasarkan pemeriksaan Imunoglobulin G

\begin{tabular}{|c|c|c|c|}
\hline \multirow{2}{*}{ Jenis } & \multicolumn{2}{|c|}{$\begin{array}{c}\text { Pemeriksaan } \\
\text { Imunoglobulin }\end{array}$} & \multirow{2}{*}{ Jumlah } \\
\cline { 2 - 3 } Kelamin & \multicolumn{2}{|c|}{ IgG } & \\
\cline { 2 - 3 } Anak & $(+)$ & $(-)$ & 9 \\
\hline Perempuan & 5 & 4 & 6 \\
Laki-laki & 2 & 4 & \\
\hline
\end{tabular}

Dari tabel 7 didapatkan bahwa dari keseluruhan pasien tidak semuanya melakukan pemeriksaan IgG, hanya 15 orang saja yang melakukan pemeriksaan tersebut. Dari pemeriksaan tersebut didapatkan 9 orang pasien perempuan dan 6 orang pasien laki-laki.

\section{BAHASAN}

Berdasarkan hasil penelitian deskriptif yang di lakukan di Bagian Anak RSU Prof. Dr. R. D. Kandou Manado periode Juli 2011 sampai Juni 2012, terdapat 60 pasien yang terinfeksi demam dengue. Dari 60 pasien dikelompokkan berdasarkan jenis kelamin, usia, pemeriksaan darah lengkap serta pemeriksaan Immunoglobulin.

Dilihat dari kelompok jenis kelamin didapatkan bahwa perbandingan 
jumlah antara anak perempuan dan anak laki-laki adalah sama yaitu sebanyak 30 anak perempuan dan 30 anak laki-laki. Hal ini sesuai dengan presentasi yang diteliti oleh Ditjen PP \& PL Depkes RI,2008 bahwa tidak terdapat perbedaan perbandingan jumlah kasus di antara keduanya.

Dilihat dari distribusi usia anak perempuan didapatkan bahwa paling banyak terinfeksi pada usia sekolah (5-12 tahun) sebanyak 14 orang anak disusul dengan usia pra sekolah (2,2-5 tahun) sebanyak 6 anak diikuti oleh usia bayi (0-1 tahun) dan usia bermain (1-2,5 tahun) sebanyak 5 orang anak.

Dilihat dari distribusi usia anak laki-laki didapatkan bahwa paling banyak terinfeksi pada usia sekolah (5-12 tahun) sebanyak 15 orang anak disusul dengan usia bayi (0-1 tahun) sebanyak 9 anak diikuti oleh usia pra sekolah (2,2-5 tahun) sebanyak 4 anak dan usia bermain (1-2,5 tahun) sebanyak 2 orang anak.

Dari data yang didapatkan bahwa dari keseluruhan pasien tidak semuanya melakukan pemeriksaan, hanya 27 orang saja yang melakukan pemeriksaan tersebut. Dari pemeriksaan tersebut didapatkan 15 orang pasien perempuan positif dan 12 orang pasien laki-laki yang positif.

Bila ada hasil NS1 yang positif menunjukkan kalau seseorang 'hampir

\section{SIMPULAN}

Berdasarkan pengamatan terhadap 60 orang pasien anak yang terinfeksi demam dengue, maka diperoleh kesimpulan :

1. Jumlah anak perempuan dan anak laki-laki yang tefinfeksi demam dengue adalah sama yakni 50:50. pasti' terkena infeksi virus dengue. Sedangkan kalau hasil NS1 Ag dengue menunjukkan hasil negatif tidak menghilangkan kemungkinan infeksi virus dengue dan masih perlu dilakukan observasi serta pemeriksaan lanjutan. Ini terjadi karena untuk mendeteksi virus dengue diperlukan kadar yang cukup dari jumlah virus dengue yang beredar, sedangkan pada fase awal mungkin belum terbentuk cukup banyak virus dengue tetapi apabila pengambilan dilakukan setelah munculnya antibodi maka kadar virus dengue juga akan turun.

Imuno serologi dilakukan pemeriksaan IgM dan IgG terhadap dengue.IgM terdeksimulai hari ke 3-5, meningkat sampai minggu ke-3, menghilang setelah 60-90 hari.IgG: pada infeksi primer, IgG mulai terdeteksi pada hari ke-14, pada infeksi sekunder IgG mulai terdeteksi hari ke-2.

Dari keseluruhan pasien tidak semuanya melakukan pemeriksaan IgM, hanya 18 orang saja yang melakukan pemeriksaan tersebut. Dari pemeriksaan tersebut didapatkan 8 orang pasien perempuan dan 10 orang pasien laki-laki.

Dari keseluruhan pasien tidak semuanya melakukan pemeriksaan IgG, hanya 15 orang saja yang melakukan pemeriksaan tersebut. Dari pemeriksaan tersebut didapatkan 9 orang pasien perempuan dan 6 orang pasien laki-laki.

2. Paling banyak di alami pada usia anak antara 5-12 tahun baik pada anak perempuan maupun laki-laki.

3. Paling sedikit di alami pada usia anak antara 1-2,5 tahun baik pada anak perempuan maupun laki-laki.

4. Seluruh anak perempuan dan anak laki-laki mengalami peningkatan eritrosit, penurunan trombosit dan leukosit. 


\section{SARAN}

Berdasarkan pengamatan terhadap 60 orang pasien anak yang terinfeksi demam dengue, maka disarankan :

1. Perlu dilakukan penelitian lebih lanjut tentang infeksi demam dengue pada anak.

2. Perlu dilakukan penelitian tetang pemeriksaan lebih spesifik pada demam dengue.

\section{DAFTAR PUSTAKA}

1. Retnowati Endang, Hidayati Wiyanda, Liana. Aktivitas Fosfolipase$\mathrm{A}_{2}$ Sekeretoris Trombositopenia Demam Berdarah Dengue. Indonesian Journal of Clinical Pathology and Medical Laborarory. Vol, 17 No. 1 November 2010

2. Aryati, Wardhani Puspita. Profil Virus Dengue di Surabaya Tahun 20082009. Indonesian Journal of Clinical Pathology and Medical Laborarory. Vol, 17 No. 1 November 2010

3. Tambunan Betty, Aryati, Husada D. Nilai Batas Antigen NS1 Dengue Kuantitatif sebagai Prediktor Keparahan Jangkitan/Tularan (Infeksi) Virus Dengue Anak . Indonesian Journal of Clinical Pathology and Medical Laborarory. Vol, 17 No. 1 November 2010

4. Aryati, Wardhani Puspita, Yohan Benediktus, Aksono Eduardus, Sasmono Tedjo. Distribusi Serotipe Dengue di Surabaya tahun 2012. Indonesian Journal of Clinical Pathology and Medical Laborarory. Vol, 19 No. 1 November 2012 5. Effendi AT, Soediono M, Suksmono HS, Erwanto B, Effendi YH, Mira Dewi. CGF $40 \%$ mempercepat Penyembuhan Penderita Demam Berdarah Dengue. Cermin Dunia Kedokteran. Vol.38 No. 2 Maret-April 2011.

\section{UCAPAN TERIMA KASIH}

Terima kasih ditujukan kepada dr. Olivia Waworuntu MPH dan dr Novie Rampengan, SpA sebagai penguji skripsi yang telah memberikan saran serta masukan yang sangat bermanfaat dalam menyelesaikan penelitian ini, serta semua pihak yang secara langsung maupun tidak langsung telah menumbuhkan gagasan dalam artikel ini.

6. Pusparini. Kadar Hematokrit dan Trombosit Sebagai Indikator Diagnosis Infeksi dengue Primer dan Sekunder. Jurnak Kedokteran Trisakti. Vol.23 No. 2 April-Juni 2004

7. WHO. Dengue Guidelines For Diagnosis, Treatment, Prevention And Control.2009. [cited: November 08,2012]. Available

from:http://apps.who.int/tdr/svc/publicatio $\mathrm{ns} /$ training-guideline-publications/denguediagnosis-treatment.

8. Sitio Anton. Hubungan Prilaku Tentang Pemberantasan Sarang Nyamuk dan Kebiasaan Keluarga dengan Kejadian Demam Berdarah Dengue di Kecamatan Medan Perjuangan Kota Medan Tahun 2008. Universitas Diponegoro Semarang (Tesis). Available at http://eprints.undip.ac.id/16497/1/ANTON SITIO.pdf

9. Noor Rasuane. Nyamuk Aedes Aegypti. Available at http://id.shvoong.com/medicine-andhealth/epidemiology-publichealth/2066459-nyamuk-aedes-aegypti/ 10. Kesmas. Karakteristik Nyamuk Demam Berdarah. Indonesianpublichealth. Available at http://www.indonesianpublichealth.com/2013/02/karakteristiknyamuk-demam-berdarah.html 